\title{
Employees' satisfaction with retention factors: exploring the role of career adaptability Coetzee, M. \& Stoltz,
}

\begin{abstract}
Given the rising concerns about staff retention and the increased importance attached to individuals' career adaptability, the present paper explored how career adaptability relates to employees' satisfaction with factors that organizations regard important for their retention. A canonical correlation analysis was conducted on a sample of 321 employees in a South African automotive industry. The results showed that career adaptability, especially career concern, significantly explained the participants' level of satisfaction with their experiences of the career opportunities, work-life balance, training and development opportunities and characteristics of the jobs offered by the company. The study findings suggest that employees' career concerns, goals and plans and how these relate to retention practices are important for retaining them. Black and white participants also differed significantly regarding the variables. This study extends prior research on career adaptability by adding insights about the usefulness of the construct in the retention context.
\end{abstract}

Keywords career adaptability, retention factors, career opportunities, training and development opportunities, job characteristics, work-life balance

Career adaptability, or the capacity to adapt, has become a central construct in vocational psychology to denote individuals' capacity to proactively construct their own careers in an increasingly more volatile employment context (Öncel, 2014; Savickas, 2013). Career 
adaptability capacities function as a source of resilience for individuals in the construction of their careers (Guan et al., 2014; Savickas \& Porfeli, 2012) and may potentially influence their attraction, retention and intention to leave (Ferreira, 2012). Research into career adaptability has increased markedly since the groundbreaking work of Savickas (1997; 2005; 2013) and Savickas and Porfeli (2012) which has been stimulated by the changing nature of careers in more turbulent employment contexts in which career paths have become more blurred and uncertain. Similarly, research into staff retention has increased in importance in the light of global skills scarcity concerns, an ageing workforce, increased career mobility opportunities for knowledge workers, rapidly changing technologies and the need for survival in a highly competitive business environment (Dietrich, 2000; Joāo and Coetzee, 2012; Mohlala et al., 2012; Samuel \& Chipunza, 2009; Van Dyk \& Coetzee, 2012).

Research shows significant associations between career adaptability and career- and work-related outcomes, such as success in the workplace, work engagement, job satisfaction, job embeddedness and organizational commitment (Ferreira, 2012; Rossier et al., 2012). However, despite the growing interest in career adaptability, more research is needed to understand the intricate relationship between individual career agency and the structures within which the career unfolds (Dany, 2014). People's careers are contextually specific and socially embedded (Dany, 2014) and influenced by their perceptions and feelings of career success and satisfaction (Fleisher et al., 2014). Research highlights the interdependency between individuals and organizations (Fleisher et al., 2014; Tams and Arthur, 2010) and that organizational business needs for success are achieved through addressing employees' career satisfaction and by balancing business needs with employees' career goals (Fleisher et al., 2014; Lips-Wiersma \& Hall, 2007). In this regard, retention research often focuses on the organizational factors and 
practices that relate to employees' job satisfaction, commitment and engagement (Döckel, 2003; Lumley et al., 2011; Van Dyk \& Coetzee, 2012). However, at present there is limited research on the link between individuals' career adaptability and specific retention-related organizational practices that influence individuals' job and career satisfaction. The goal of the present study was therefore to explore multivariate relationships of the career adaptability and retention factor satisfaction constructs.

Afiouni and Karam (2014) postulate that individuals' perception of career success and satisfaction is constructed through the interaction of individuals' agency with their context and the agentic processes by means of which individuals adapt to facilitate better alignment between personal preferences and needs and the structural contexts in which they pursue the career. In line with this reasoning, career adaptability is seen as the self-regulatory meta-capacities or resources employed to facilitate person-structural alignment in order to enhance career success and satisfaction (Savickas \& Porfeli, 2012). Research by Zacher (2014) indicated positive associations between career adaptability and perceived career success. Retention factors are seen to represent certain characteristics of the structure within which the career is pursued and that relate to measures of career success or satisfaction.

The paper makes several contributions to the career and retention literature. First, empirical evidence is provided supporting the growing, yet to date limited, research on the potential positive implications of individuals' career adaptability for the organization that employs them (e.g., Ferreira 2012; Rossier et al., 2012). Second, given that career adaptability and retention factor satisfaction are multi-factorial constructs, we test multivariate relationships between the career adaptability and retention factor constructs. By doing so, our research highlights the core career adaptability capacities that play an important role in explaining 
individuals' satisfaction with key retention factors. This approach may potentially contribute to a deeper understanding of how to achieve better alignment between individuals' sense of career agency (embedded in their career adaptability) and the structural context in which the career is pursued (as represented by the specific retention factors).

\section{Career adaptability}

The construct of career adaptability denotes a multidimensional, hierarchical structure of four key resources or adapt-abilities (Maggiori et al., 2013; Savickas \& Porfeli, 2012): career concern, career control, career curiosity and career confidence. These dimensions reflect the ability to look ahead to one's future, considering and preparing for future career possibilities (concern), to know what career to pursue and making deliberate decisions and taking conscientious action (control), to look around at options, exploring various situations and potential roles (curiosity), and to have the self-efficacy to undertake activities needed to achieve career goals (confidence) (Savickas \& Porfeli, 2012). In contrast to individual adaptability (an individual's general ability, skill, dispositions, willingness and/or motivation to change or fit different task, social and environmental features), career adaptability appears to denote situationspecific evaluation goals (Hamtiaux et al., 2013). In this regard, career concern is seen as the fundamental dimension of career adaptability given the elements of future time perspective, active involvement in, planfulness, awareness and optimism about the achievability of future goals embedded in the construct (Perera \& McIlveen 2014). Career control reflects the perceived personal control over the vocational future and the belief about personal responsibility for constructing one's career. Curiosity about possible selves and social opportunities increases people's active exploration behaviors. Career confidence includes the capacity to stand by one's 
own aspirations and objectives, even in the face of obstacles and barriers (Savickas \& Porfeli, 2012; Stoltz, 2014).

Career adaptability presumes meaningful adaptation through agentic processes within a specific work environment (Savickas \& Porfeli, 2012). These processes refer to individuals' capacity to act and to make their own choices (agency) within, or in interacting with, the constraints of a structure such as for example those associated with a particular organizational or social environment. Agentic processes lead to response choices that facilitate career choices and behavior which influence individuals' career success and satisfaction (Afiouni \& Karam, 2014) and potentially their turnover behavior (Ferreira, 2012). Research indicates career adaptability to be positively associated with future job search self-efficacy, employment status, perceptions of the future work self and person-environment fit (Guan et al., 2014). High levels of career adaptability are also seen to positively predict levels of career satisfaction (Zacher, 2014), work engagement (Rossier et al., 2012) and perceived well-being and of control over one's own life (Hirschi, 2009; Öncel, 2014). Career adaptability resources are presumed to help prevent personjob mismatch and underemployment and positively influence career satisfaction and retention (Gutman \& Schoon, 2012; McKee-Ryan \& Harvey, 2011; Takase et al., 2012).

\section{Retention factors}

Retention research increasingly focuses on identifying organizational practices as key factors that may contribute to the retention of staff. Döckel's (2003) research identified a set of specific factors that may influence staff retention. These include factors such as compensation (monetary and non-monetary rewards; job characteristics (skill variety and job autonomy); training and development opportunities (formal development activities provided by the 
organization); supervisor support (recognition by and feedback from supervisors to employees); career opportunities (internal and external career options an employee may have); work-life balance (employee's ability to meet both work and family commitments); and organizational commitment (employee's emotional attachment to, identification with, and involvement in the organization). Research has provided evidence that these retention factors contribute to reduced voluntary turnover, lower intentions to leave, enhanced productivity, more committed and satisfied employees and the effective management of retention practices (Döckel, 2003; Ferreira, 2012; Joäo, 2010; Kraimer et al., 2011; Morrow, 2011). In a South African-based study amongst professionally skilled staff, Du Toit (2012) identified various themes relating to perceptions of career success. These include learning and development, skills experience and competence, career transitions/advancement, job content, relationship to the organization, achievement of goals, reward and recognition and work-life balance. All of these themes are congruent with the retention factors identified by Döckel (2003), implying that satisfaction with retention factors may be related to perceptions of career success. However, it is not clear how individuals' career behavior and capacities in planning, managing and constructing their careers (career adaptability) in a specific work environment relate to their satisfaction with organizational practices that influence their career success and turnover intention.

Kyndt, Docky, Michielsen, and Moeyaert (2009) highlight that the implementation of retention practices facilitate employee engagement. A study conducted by Bontis, Richards, and Serenko (2011) indicated that autonomy and challenging work, both being retention factors, contribute to employee satisfaction. João (2010) also found that the need for career growth and opportunities for advancement, as well as challenging work, are significant factors that stop professionally qualified employees from leaving their organizations. Organizations that fulfill 
employees' needs regarding the retention factors also encourage organizational commitment (Döckel, 2003; Pauw, 2011). According to Pauw (2011), commitment and connection to the organization have a direct influence on employee retention. In line with the research literature, we expected that career adaptability would further help to explain employees' satisfaction with retention factors $(\mathrm{H} 1)$.

\section{Method}

\subsection{Participants}

Data for the study were collected from 321 permanently employed employees in a South African automotive manufacturing company. The respondents comprised 231 (72 per cent) male and 90 ( 28 per cent) females whose ages ranged predominantly between 20 and 49 years ( 74 per cent). The sample was represented by 50 percent white and 50 percent black employees. The majority of the respondents were on a managerial/supervisory level (79 per cent) and 21 percent were operational level staff. The majority of the respondents have been in the company's employment for more than six years (64 percent) and less than 5 years ( 36 per cent).

\subsection{Procedure}

Ethical clearance to conduct the study was obtained from the Research Ethics Committee of the research institution. Permission for the research was obtained from the human resource director of the company. Data were collected through questionnaires administered during working hours in individual and group sessions. Five-hundred and twenty-eight (528) questionnaires were distributed and 321 questionnaires with complete data were returned, yielding a response rate of 61 per cent. The participants were invited to voluntarily participate 
and signed an informed consent form. The privacy, anonymity and confidentiality of all the participants were ensured and honored.

\subsection{Measures}

Career adaptability was measured by means of the Career Adapt-Abilities Scale (CAAS). The CAAS (Savickas \& Porfeli, 2012) is a multi-factorial self-rating measure, consisting of 24 items and four subscales: concern (6 items, for example "Thinking about what my future will be like"), control (6 items, for example "Taking responsibility for actions"), curiosity (6 items, for example "Becoming curious about new opportunities"), and confidence (6 items, for example "Performing tasks efficiently"). A 5-point Likert-type scale (1= not strong; 5 $=$ strongest) is used for subjects' responses to each of the 24 items. Maree (2012) confirmed the construct validity and internal consistency reliability of the CAAS in the South African context. In terms of the present sample, the overall scale obtained a reliability coefficient of .94 . The following Cronbach Alpha coefficients (internal consistency) for the four subscales were obtained: career concern (.85), career control (.82), career curiosity (.88) and career confidence (.89).

Retention factor satisfaction was measured using the Retention Factor Scale (RFS) which was developed in the South African organizational context by Döckel (2003). The RFS measures the participants' satisfaction with the following retention factors on a 6-point Likerttype scale $(1=$ strongly dissatisfied; 6 = strongly satisfied): compensation (13 items, for example "On my present job this is how I feel about my benefits package"), job characteristics (4 items, for example "The job requires me to use a number of complex or high-level skills"), training and development opportunities (6 items, for example "The company is providing me with job-specific 
training"), supervisor support (6 items, for example "My supervisor looks for opportunities to praise positive employee performance, both privately and in front of others"), career opportunities (6 items, for example "My chances for being promoted are good"), work-life balance (4 items, for example "I often feel like there is too much work to do") and commitment to the organization (3 items, for example "How would you rate your chances of still working at this company a year from now"). A factor analysis on the RFS conducted by Döckel (2003) confirmed the construct validity of the questionnaire in the South African context. In terms of internal consistency reliability, the following Cronbach's Alpha coefficients were obtained for the present sample: compensation (.96), job characteristics (.60), training and development opportunities (.91), supervisor support (.79), career opportunities (.72), work-life balance (.86) and commitment to the organization (.77). The overall scale obtained a reliability coefficient of .93.

Demographic data were used as control variables and included: age (coded $0=\leq 45$ years; $1=\geq 46$ years $)$, gender $($ coded $0=$ male; $1=$ female $)$, and race $($ coded $0=$ black; $1=$ white). These variables were chosen based on previous research indicating that these variables are important to consider in the retention of employees (Ferreira, 2012; Joāo \& Coetzee, 2012; Stoltz, 2014; Van Dyk \& Coetzee, 2012).

\subsection{Statistical analyses}

Due to the cross-sectional nature of the research design, we first ran Harmann's onefactor solution and confirmatory factor analysis to test for common method variance. The onefactor solution showed that the single factor that emerged for the CAAS accounted for $44 \%$ of the covariance among the CAAS variables. The four variables were then loaded onto one factor 
to examine the fit of the confirmatory factor analysis (CFA) model. The CAAS single-factor model did not fit the data well $(\mathrm{CMIN} / \mathrm{df}=6.82 ; p=.00 ; \mathrm{CFI}=.98 ; \mathrm{RMSEA}=.14)$. The onefactor solution for the RFS showed that the RFS construct accounted for $31 \%$ of the covariance among the RFS variables. When loading the seven RFS variables onto a single construct in the CFA model, the fit indices showed that the single factor did not fit the model well $(\mathrm{CMIN} / \mathrm{df}=$ 2.92; $\mathrm{p}=.00 ; \mathrm{CFI}=.84 ; \mathrm{RMSEA}=.08)$. In line with the guidelines of Podsakoff, MacKenzie, Lee, and Podsakoff (2003), the one-factor results suggested that common method bias did not pose a threat to our findings.

We then tested the fit of the measurement model before proceeding with the statistical analyses. The measurement model comprised 37 indicators and 11 first-order factors with the following fit indices: $\mathrm{CMIN} / \mathrm{df}=2.79 ; \mathrm{p}=.00 ; \mathrm{CFI}=.94 ; \mathrm{RMSEA}=.08$. The results showed that the data fit the model well. Bivariate correlation (Pearson's coefficients) analyses were then calculated to assess the pattern of relationships between the variables of concern to the study. Point-biserial correlations were calculated for discrete dichotomous variables (i.e. the demographic variables). Canonical correlation analysis was used to study the multivariate relationships between the four CAAS scores and the seven RFS scores.

\section{Results}

\subsection{Correlations}

As can be seen from Table 1, the practical effect of the significant inter-correlations among the CAAS and RFS variables ranged between $r \geq .10 \leq .26$ (small effect; $p \leq .05$ ). Similarly, the significant inter-correlations among the CAAS and RFS variables were also small in practical effect $(r \geq .10 \leq .28 ; p \leq .05)$, suggesting no multi-collinearity. With the exception of 
race $($ coded $0=$ black; $1=$ white), the other associations between age and gender and the CAAS and RFS variables were regarded as negligible. Race had significant negative correlations $(r \geq-$ $.17 \leq-.31 ; p \leq .05 ;$ small to moderate practical effect) with all the career adaptability variables and the RFS training and development, career opportunities and work-life balance variables $(r \geq$ $-.13 \leq-.25 ; p \leq .05 ;$ small practical effect). Race correlated positively with compensation and organizational commitment $(r \geq .15 \leq .16 ; p \leq .05$; small practical effect).

Insert Table 1 approximately here

Canonical correlation analysis was used to study the multivariate relationships between the four CAAS scores (career concern, career control, career curiosity, and career confidence) and the seven RFS scores (compensation, job characteristics, training and development opportunities, supervisor support, career opportunities, work-life balance and organizational commitment). Table 2 shows that the full model was significant using Wilks's multivariate test criterion. Wilks's lambda $(\lambda)=.79$, function $1: \mathrm{F} p=2.17(p=.0001)$. Only the first function of the model was significant and contributed to $64 \%$ of the overall explained variation relative to the function. The full model $r^{2}$ type effect size (yielded by $1-\lambda$ ) was .21 (moderate practical effect), indicating that the full model explains an adequate proportion, about $21 \%$ of the variance shared between the two variable sets. The redundancy index results summarized in Table 2 shows that career adaptability explained $14 \%\left(R c^{2}=14\right.$; moderate practical effect $)$ of the variance in retention factor satisfaction and was able to predict 3\% (small practical effect) of the proportion of variance in the individual original retention factor satisfaction variables. 
Table 2 provides the canonical coefficients (weights), canonical structure coefficients $(R c)$, canonical cross-loadings $(R c)$ and squared canonical loadings $\left(R c^{2}\right)$. Only those dependent variables (RFS) that exceeded an $R c$ greater than .30 were used in the interpretation: job characteristics, training and development opportunities, career opportunities and work-life balance. These four RFS variables all loaded positively with the retention factor satisfaction canonical construct and were assumed to represent high retention factor satisfaction. Career opportunities was indicated as the strongest predictor of the retention factor satisfaction canonical construct $(R c=.84)$, followed by work-life balance $(R c=.51)$, training and development opportunities $(R c=.50)$, and job characteristics $(R c=.38)$.

Table 2 shows career concern as the strongest predictor of the career adaptability canonical construct $(R c=.96)$ and the variable that exhibited the highest correlation with the canonical retention factor satisfaction variable $(R c=.36)$. As expected, career opportunities exhibited the highest correlation with the canonical career adaptability variable $(R c=.31)$. All the career adaptability variables contributed significantly in explaining the variance in the four original retention factor satisfaction variables (moderate practical effect): career opportunities (10\%), work-life balance (4\%), training and development opportunities (4\%), and job characteristics $(2 \%)$.

Insert Table 2 approximately here

\subsection{Test for significant mean differences between the race groups}

The significant zero-order correlation results suggested that the black and white participants differed significantly regarding their career adaptability and satisfaction with the 
retention factors. We therefore decided to run a t-test to test for significant differences between the black and white participants regarding the CAAS and RFS variables. Table 3 shows that the black participants scored significantly higher than their white counterparts on all the career adaptability variables ( $p=.0001 ; d \geq .34 \leq .91$; moderate to large practical effect) and, with the exception of job characteristics and supervisor support (no significant differences), training and development opportunities, career opportunities and work-life balance $(p=.05 ; d \geq .34 \leq .91$; small to large practical effect). The white participants scored significantly higher than the black participants on compensation and organizational commitment $(p=.05 ; d \geq .30 \leq .33$; small practical effect).

Insert Table 3 approximately here

\section{Discussion}

The study explored multivariate relationships of the career adaptability and retention factor satisfaction variables. As expected $(\mathrm{H} 1)$, the results provided evidence that career adaptability explained employees' satisfaction with retention factors. The discussion focuses on the core variables highlighted in the canonical correlation results.

\subsection{Career adaptability in relation to retention factor satisfaction}

The results showed that career adaptability, especially career concern, significantly explained the participants' level of satisfaction with their experiences of the career opportunities, work-life balance, training and development opportunities and characteristics of the jobs offered by the company. These retention factors were shown to relate to individuals' perceptions of 
career success (Du Toit \& Coetzee, 2012) and their retention (Döckel, 2003; Joāo \& Coetzee, 2012; Lesabe \& Nkosi, 2007) in the South African organizational context.

The results of the study confirmed that concerns about one's career are especially highly associated with the perceived career opportunities offered by the organization. Career concern (having a future perspective about one's career) was also confirmed to be fundamental to the construct of career adaptability (Perera and McIlveen 2014) which explains the strong positive association with future career development opportunities in the organization. Du Toit and Coetzee (2012) identified individuals' needs for career transitions or advancements as an important aspect of their perceptions of objective career success. Nabi (2003) indicated in this regard that future career prospects provide a sense of job security which is characterized by a sense of stability about one's job continuity that contributes to feelings of subjective career success.

The results further indicated work-life balance as an important aspect of the participants' career adaptability and especially their concern about the future of their careers. The results seem to corroborate Park's (2010) finding that individuals seek to incorporate their roles at work into the broader perspective of their lives. Du Toit and Coetzee (2012) also found individuals' need for balancing their career needs with other aspects of their life as an important facet of their perceptions of subjective career success. Research on retention factors by Joāo and Coetzee (2012) indicated the ability to balance one's work and life as a key factor in retaining professionally skilled staff.

Career concern further appeared to be positively associated with the need for job-related and professional training and development opportunities in the organization. This might be due 
to the positive contribution of enhanced training and development on employees' chances to experience career advancement (Nienaber et al., 2011). The findings further appear to support the notion of growth implied in the career adaptability construct as postulated by Dix and Savickas (1995). Research by Du Toit (2012) indicated the growth processes underpinning individuals' need for career and personal growth and development as important aspects of their subjective career success. Accessibility and availability of training and career pathing are seen as essential to individuals' personal and organizational growth (Lesabe \& Nkosi, 2007). Allen, Shore, and Griffeth (2003) found growth opportunities to significantly influence attitudes toward the organization and turnover intention.

The results of the present study further suggest that individuals who are highly concerned about their careers would also tend to be more concerned about the nature of their jobs. The nature of one's work is seen as an intrinsic motivator and an aspect of individuals' subjective

career success (Du Toit \& Coetzee, 2012) and job satisfaction (Warr, 2002; Westlund and Hannon, 2008). Job characteristics relate to the need for autonomy and freedom in applying one's skills and knowledge in performing high-level or complex tasks and using one's initiative in solving challenging problems on the job (Döckel, 2003). Westlund and Hannon (2008) found satisfaction with the nature of work to be significantly related to an employee's intention to leave an organization.

\subsection{Differences between the race groups}

Our study contributes several important insights into the career adaptability and satisfaction of black and white employees. The black participants showed higher levels of career adaptability than the white participants. The enhanced level of career adaptability of the black 
employees might be attributed to the positive influence of the increased intra-organizational career opportunities available to especially black people in the post-apartheid South African workplace which require a higher level of career adaptability from black employees. This is congruent with findings by Joäo and Coetzee (2012) who found that black employees in the South African organizational context consider career advancement and growth opportunities and career development support to be more important than any other racial group. They might therefore also tend be less satisfied with their compensation and be less committed to the organization than the white employees. The higher levels of satisfaction of the black participants with the career and training and development opportunities that the company offers could also be attributed to the South African employment equity, affirmative action and skills development legislation that provide them with enhanced career and training and development opportunities. Finally, the results of our study also corroborate previous research indicating that white employees value work-life balance more than black employees, and therefore tend to be the least satisfied with their work-life balance (Van Dyk \& Coetzee, 2012).

\subsection{Implications}

The study has several important implications for employees' career satisfaction and by implication their retention. First, the study highlights the link between employees' career concern and their satisfaction with key retention factors. Addressing individuals' career concern is fundamental to their career adaptability and satisfaction (Perera \& McIlveen, 2014). Employees' career concern capacities can be developed by actively engaging them in career discussions that focus on career development planning involving the setting of realistic career goals, and helping the individual to plan and prepare for future career possibilities (Del Corso, 2013). Career discussions supported by mentoring and coaching might further support 
individuals in developing the career adapt-abilities they need to proactively construct their careers in today's workplace (Schreuder \& Coetzee, 2011). Apart from the planfulness and optimism about the achievability of future goals (career concern), career discussions around career goals and plans might further stimulate career control (i.e. perceived sense of control over one's future and deliberate decisions and actions), career curiosity (exploration of options and potential roles) and career confidence (self-efficacy in undertaking the actions needed to achieve career goals) (Del Corso, 2013; Savickas \& Porfeli, 2012). Second, the results of our study showed that these career adapt-abilities positively predict satisfaction with organizational retention practices that support the career development of individuals. Management should be aware of black and white employees' career goals and plans and ensure that supportive human resource practices (e.g. career and training and development opportunities and work-life balance policies) are in place should they wish to retain their employees.

Finally, our study points out the importance of alignment between employees' career concerns and the nature of their jobs in retention considerations. Challenging work increases perceived influence on career situations and positively contributes to career adaptability (Brown et al., 2012). Career and job discussions, job enrichment, written job and career goals and organizational support in the form of career and training and development opportunities may in general help to increase perceptions of career success and satisfaction for employees (Brundage \& Koziel, 2010).

\subsection{Limitations and directions for future research}

Several limitations need to be noted in the interpretation of the results. First, canonical correlation analysis is a maximization technique, and, therefore, the results of this study are to be 
interpreted with caution. When interpreting models of canonical correlation, researchers and practitioners should be aware of the possibility of overestimation due to the amplification of linear composites (Hair et al., 2010). Second, the sample was confined to a specific population in the South African automotive industry which limits the interpretability of the results to populations in different occupational industries. Testing the variables on various multicultural populations from various occupational groups may further inform theories of career adaptability in the retention context. Finally, the cross-sectional nature of our study limits the nature of data obtained to a specific moment in time. Much would be gained by future longitudinal research analyzing the shift in levels of career adaptability and retention factor satisfaction as the career self-concept evolves over time.

\subsection{Conclusion}

The results of the study offer potentially new insights for managers and practitioners to consider in the retention of staff in the contemporary career context. Following a multivariate approach to assessing the relationship between career adaptability and retention factor satisfaction offered additional insights about the construct of career adaptability in organizational context. Overall, it can be concluded that employees' career concerns, goals and plans and how these relate to retention practices are important for retaining them.

\section{Acknowledgements}

None

\section{References}


Afiouni, F. \& Karam, C.M. (2014). Structure, agency and notions of career success: A processoriented, subjectively malleable and localized approach. Career Development International, 19(5), 548-571.

Allen, D.G., Shore, L.M., \& Griffeth, R.W. (2003). The role of perceived organizational support and supportive human resource practices in the turnover process. Journal of Management, 29(1), 99-118.

Arbuckle, J. L. (1995-2009). Amos 18 User's Guide. Crawfordville, FL: Amos Development Corporation.

Bontis, N., Richards, D., \& Serenko, A. (2011). Improving service delivery. The Learning Organization, 18(3), 239-250.

Brown, A., Bimrose, J., Barnes, S-A., \& Hughes, D. (2012). The role of career adaptabilities for mid-career changers. Journal of Vocational Behavior, 80, 754-761.

Brundage, H. \& Koziel, M. (2010). Retaining top talent. Journal of Accountancy, May, 38-44.

Dany, F. (2014). Time to change: The added value of an integrative approach to career research. Career Development International, 19(6) http://dx.doi.org/10.1108/CDI-06-2014-0075

Dietrich, N. (2000). Skills will be the secret to retention success in the 21 st century. HR Focus, February, 7-10.

Dix, J.E. \& Savickas, M.L. (1995). Establishing a career: developmental tasks and coping responses. Journal of Vocational Behavior, 47, 93-107.

Döckel, A. (2003). The effect of retention factors on organisational commitment: An investigation of high technology employees, Unpublished master's thesis, University of Pretoria, Pretoria, South Africa.

Del Corso, J.L. (2013). The theory of career adaptability. In A. Di Fabio \& J.G. Maree (Eds.), 
The psychology of career counseling: New challenges for a new era (pp. 117-130). New York: Nova Science Publishers, Inc.

Du Toit, D. (2010). The relationship between archetypal values, career orientations, perceived career success and meaningfulness, Unpublished master's dissertation, University of South Africa, Pretoria.

Du Toit, D. \& Coetzee, M. (2012). Exploring the perceived career success of staff in a South African science and engineering company. Journal of Psychology in Africa, 22(1), 96105.

Ferreira, N. (2012). Constructing a psychological career profile for staff retention, Unpublished doctor's thesis, University of South Africa, Pretoria, South Africa.

Fleisher, C., Khapova, S., \& Jansen, P. (2014). Effects of employees` career competencies development on organisations: Does satisfaction matter? Career Development International, 10(6), http://dx.doi.org/10.1108/CDI-12-2013-0150

Guan, Y., Guo, Y., Bond, M.H., Cai, Z., Zhou, X., Xu, J., Zhu, F., Wang, Z., Fu, R., Liu, S., Wang, Y., Hu, T., \& Ye, L. (2014). New job market entrants' future work self, career adaptability and job search outcomes: examining mediating and moderating variables”, Journal of Vocational Behavior, 85, 136-145.

Gutman, L.M., \& Schoon, I. (2012). Correlates and consequences of uncertainty in career aspirations: gender differences among adolescents in England. Journal of Vocational Behavior, 80(3), 608-618.

Hair, J., Black, W., Babin, B., \& Anderson, R. (2010). Multivariate data analysis. Pearson Education, Englewood Cliffs, NJ.

Hamtiaux, A., Houssemand, C., \& Vrignaud, P. (2013). Individual and career adaptability: comparing models and measures. Journal of Vocational Behavior, 83, 130-141. 
Hirschi, A. (2009). Career adaptability development in adolescence: multiple predictors and effect on sense of power and life satisfaction. Journal of Vocational Behavior, 74, 145155.

Joāo, T.F. (2010). The relationship between perceived career mobility, career mobility preference, job satisfaction and organisational commitment, Unpublished master's thesis, University of South Africa, Pretoria, South Africa.

Joāo, T.F. \& Coetzee, M. (2012). Job retention factors, perceived career mobility and organisational commitment in the South African financial sector. Journal of Psychology in Africa, 22(1), 69-76.

Kraimer, M.L., Seibert, S.E., Wayne, S.J., Liden, R.C., \& Bravo, J. (2011). Antecedents and outcomes of organizational support for development: the critical role of career opportunities. Journal of Applied Psychology, 96(3), 485-500.

Kyndt, E., Docky, F., Michielsen, M., \& Moeyaert, B. (2009). Employee retention: organisational and personal perspectives. Vocations and Learning, 2, 195-215.

Lesabe, R.A., \& Nkosi, J. (2007). A qualitative exploration of employees' views on organisational commitment. South African Journal of Human Resource Management, $5(1), 35-44$.

Lips-Wiersma, M. \& Hall, D.T. (2007). Organizational career development is not dead : A case study on managing the new career during organizational change. Journal of Organizational Behavior, 28(6), 771-792.

Lumley, E.J., Coetzee, M., Tladinyane, R.T., \& Ferreira, N. (2011). Exploring the job satisfaction and organisational commitment of employees in the Information Technology environment. Southern African Business Review, 15(1), 100-118. 
Maggiori, C., Johnston, C.S., Krings, F., Massoudi, K., \& Rossier, J. (2013). The role of career adaptability and work conditions on general and professional well-being. Journal of Vocational Behavior, 83, 437-449.

Maree, J.B. (2012). Career Adapt-abilities Scale - South African Form: Psychometric properties and construct validity. Journal of Vocational Behavior, 80, 730-733.

McKee-Ryan, F.M., \& Harvey, J. (2011). I have a job, but...': A review of underemployment”, Journal of Management, 37(4), 962-996.

Mohlala, J., Goldman, G.A., \& Goosen, X. (2012). Employee retention within the Information Technology division of a South African bank. South African Journal of Human Resource Management, 10(2), 1-11.

Morrow, P.C. (2011). Managing organizational commitment: Insights from longitudinal research. Journal of Vocational Behavior, 79, 18-35.

Nabi, G.L. (2003). Situational characteristics and subjective career success. International Journal of Manpower, 24(6), 653-671.

Nienaber, R., Bussin, M.H.R., \& Henn, C. (2011). The relationship between personality types and reward preferences. Acta Commercii, 11(2), 56-79.

Öncel, L. (2014). Career Adapt-Abilities Scale: convergent validity of subscale scores. Journal of Vocational Behavior, 85, 13-17.

Park, Y. (2010). The predictors of subjective career success: an empirical study of employee development in a Korean financial company. International Journal of Training and Development, 14(1), 1-15. 
Pauw, D. (2011). The influence of leaders' personality types and emotional intelligence on retention factors, Unpublished master's thesis, University of South Africa, Pretoria, South Africa.

Perera, H.N. \& Mcllveen, P. (2014). The role of optimism and engagement coping in College adaptation: a career construction model. Journal of Vocational Behavior, 84, 395-404.

Podsakoff, P.M., MacKenzie, S.B., Lee, J.Y., \& Podsakoff, N.P. (2003). Common method biases in behavior research: A critical review of the literature and recommended remedies. Journal of Applied Psychology, 88, 879-903.

Rossier, J., Zecca, G., Stauffer, S., Maggiori, C., \& Dauwalder, J.P. (2012). Career AdaptAbilities Scale in a French-speaking Swiss Sample: psychometric properties and relationships to personality and work engagement. Journal of Vocational Behavior, 80(3), 734-743.

Samuel, M., \& Chipunza, C. (2009). Employee retention and turnover: using motivational variables as a panacea. African Journal of Business Management, 3(8), 410-415.

Savickas, M.L. (1997). Adaptability: an integrative construct for life-span, life-space theory", Career Development Quarterly, 45, 247-259.

Savickas, M.L. (2005). The theory and practice of career construction. In Lent, R.W. \& Brown, S.D. (Eds.), Career Development and Counseling: Putting Theory and Research to Work (pp. 42-70). Hoboken, NJ: John Wiley \& Sons.

Savickas, M.L. (2013). Career construction theory and practice. In Lent, R.W. \& Brown, S.D. (Eds.), Career Development and Counselling: Putting Theory and Research to Work ( $2^{\text {nd }}$ ed., pp. 147-183). Hoboken, NJ: John Wiley \& Sons. 
Savickas, M.L., \& Porfeli, E.J. (2012). Career Adapt-abilities Scale: construction, reliability, and measurement equivalence across 13 Countries. Journal of Vocational Behavior, 80, 661673.

Stoltz, E. (2014). Employability attributes and career adaptability as predictors of staff satisfaction with retention factors. Unpublished master's thesis, University of South Africa, Pretoria, South Africa.

Schreuder, A.M.G. \& Coetzee, M. (2011). Careers: An organisational perspective (4th edition). Cape Town: Juta.

Takase, M., Nakayoshi, Y., \& Teraoka, S. (2012). Graduate nurses‘ perceptions of mismatches between themselves and their jobs and association with intent to leave employment: a longitudinal survey. International Journal of Nursing Studies, 49(12), 1521-1530.

Tams, S. \& Arthur, M.B. (2010). New directions for boundaryless careers: agency and interdependence in a changing world. Journal of Organizational Behavior, 31(5), 629646.

Van Dyk, J., \& Coetzee, M. (2012). Retention factors in relation to organisational commitment in Medical and Information Technology Services. South African Journal of Human Resource Management, 10(2), 1-11.

Warr, P.B. (2002). The study of well-being, behavior and attitudes. In Warr, P.B. (Ed.), Psychology at Work (pp. 1-25). London: Penguin.

Westlund, S., \& Hannon, J. (2008). Retaining talent: assessing job satisfaction facets most significantly related to software developer turnover intentions. Journal of Information Technology Management, 19(4), 1-15. 
Zacher, H. (2014). Individual difference predictors of change in career adaptability over time. Journal of Vocational Behavior, 84,188-198.

Zacher, H., \& Frese, M. (2009). Remaining time and opportunities at work: relationships between age, work characteristics, and occupational future time perspective. Psychology and Aging, 24(2), 487-493. 
Table 1

Descriptive statistics and bivariate correlations

\begin{tabular}{|c|c|c|c|c|c|c|c|c|c|c|c|c|c|c|c|c|c|c|c|c|}
\hline & & M & SD & $\alpha$ & 1 & 2 & 3 & 4 & 5 & 6 & 7 & 8 & 9 & 10 & 11 & 12 & 13 & 14 & 15 & 16 \\
\hline 1 & Age & - & - & - & - & & & & & & & & & & & & & & & \\
\hline 2 & Gender & - & - & - & -.05 & - & & & & & & & & & & & & & & \\
\hline 3 & Race & - & - & - & $.22^{* \star *}$ & -.08 & - & & & & & & & & & & & & & \\
\hline 4 & $\begin{array}{l}\text { Career } \\
\text { concern }\end{array}$ & 3.87 & .71 & .85 & $-.19^{* * *}$ & .07 & $-.41^{* * *}$ & - & & & & & & & & & & & & \\
\hline 5 & Career control & 4.06 & .57 & .82 & .003 & .06 & -.19 .** & $.61^{* * *}$ & - & & & & & & & & & & & \\
\hline 6 & $\begin{array}{l}\text { Career } \\
\text { curiosity }\end{array}$ & 3.88 & .70 & .88 & -.09 & .003 & $-.26^{*}$ & $.61^{* * *}$ & $.69^{* * *}$ & - & & & & & & & & & & \\
\hline 7 & $\begin{array}{l}\text { Career } \\
\text { confidence }\end{array}$ & 4.12 & .62 & .89 & -.03 & .02 & $-.17^{* *}$ & $.55^{\star * *}$ & $.75^{\star \star *}$ & $.77^{* * *}$ & - & & & & & & & & & \\
\hline 8 & $\begin{array}{l}\text { Overall career } \\
\text { adaptability }\end{array}$ & 3.99 & .55 & .94 & -.10 & .04 & $-.31^{* * *}$ & $.80^{* * *}$ & $.87^{* * *}$ & $.89^{* * *}$ & $.88^{* * *}$ & - & & & & & & & & \\
\hline 9 & Compensation & 3.64 & 1.16 & .96 & .002 & .04 & $.15^{\star *}$ & .04 & -.03 & -.09 & -.02 & -.04 & - & & & & & & & \\
\hline 10 & $\begin{array}{l}\text { Job } \\
\text { characteristics }\end{array}$ & 4.49 & .88 & .60 & $.11^{*}$ & $-.11^{*}$ & .10 & $.14^{*}$ & .08 & .08 & $.17^{* *}$ & $.11^{*}$ & $.28^{* * *}$ & - & & & & & & \\
\hline 11 & $\begin{array}{l}\text { Training \& } \\
\text { development } \\
\text { opportunities }\end{array}$ & 3.62 & 1.21 & .91 & .01 & -.04 & $-.13^{*}$ & $.17^{\star \star}$ & .07 & .06 & .08 & .08 & $.49^{\star \star \star}$ & $.27^{\star \star \star}$ & - & & & & & \\
\hline 12 & $\begin{array}{l}\text { Supervisor } \\
\text { support }\end{array}$ & 4.29 & 1.06 & .79 & -.07 & -.02 & .02 & .09 & $.10^{*}$ & .09 & $.12^{*}$ & $.11^{*}$ & $.36^{\star \star *}$ & $.38^{\star \star *}$ & $.32^{\star \star \star}$ & - & & & & \\
\hline 13 & $\begin{array}{l}\text { Career } \\
\text { opportunities }\end{array}$ & 3.46 & .96 & .72 & $-.18^{\star \star *}$ & -.06 & $-.13^{*}$ & $.28^{\star \star *}$ & $.15^{* *}$ & $.12^{*}$ & $.13^{*}$ & $.20^{* * *}$ & $.46^{\star \star *}$ & $.31^{* \star *}$ & $.53^{\star \star *}$ & $.39^{\star * *}$ & - & & & \\
\hline 14 & $\begin{array}{l}\text { Work-life } \\
\text { balance }\end{array}$ & 3.87 & 1.24 & .86 & .05 & .02 & $-.25^{\star * *}$ & $.18^{* * *}$ & .09 & .02 & .06 & .08 & $.18^{* * *}$ & .06 & $.20^{\star * *}$ & $.24^{* * *}$ & $.26^{\star \star *}$ & - & & \\
\hline 15 & $\begin{array}{l}\text { Organisational } \\
\text { commitment }\end{array}$ & 4.71 & 1.27 & .77 & $.21^{* * *}$ & -.06 & $.16^{* *}$ & .007 & .009 & -.02 & .04 & .003 & $.40^{\star * *}$ & $.36^{\star \star *}$ & $.35^{\star \star *}$ & $.32^{* * *}$ & $.35^{\star \star \star}$ & $.12^{\star}$ & - & \\
\hline 16 & $\begin{array}{l}\text { Overall } \\
\text { retention } \\
\text { factor } \\
\text { satisfaction }\end{array}$ & 3.88 & .76 & .93 & .001 & -.02 & .02 & $.17^{\star *}$ & .06 & -.01 & .07 & .10 & $.84^{\star * *}$ & $.49^{* * *}$ & $.72^{\star * *}$ & $.63^{* * *}$ & $.71^{* * *}$ & $.40^{* * *}$ & $.57^{* \star *}$ & - \\
\hline
\end{tabular}

Notes: $\mathrm{N}=321$. Significant correlations are in boldface. ${ }^{* * *} p \leq .001-$ statistically significant. $* * p \leq .01-$ statistically significant. $* p \leq .05-$ statistically significant. 
Table 2

Results of the standardized canonical correlation analysis for the first canonical function

\begin{tabular}{|c|c|c|c|c|}
\hline Variate/variables & $\begin{array}{l}\text { Canonical } \\
\text { coefficients }\end{array}$ & $\begin{array}{l}\text { Structure } \\
\text { coefficient } \\
(R c)\end{array}$ & $\begin{array}{l}\text { Canonical } \\
\text { cross- } \\
\text { loadings } \\
(R c)\end{array}$ & $\begin{array}{l}\text { Squared } \\
\text { canonical } \\
\text { loadings } \\
\left(R c^{2}\right) \\
\end{array}$ \\
\hline \multicolumn{5}{|c|}{ Career adaptability canonical variate variables } \\
\hline Career concern & 0.31 & 0.96 & 0.36 & $\mathbf{0 . 1 3}$ \\
\hline Career control & -0.83 & 0.43 & 0.16 & 0.03 \\
\hline Career curiosity & -1.16 & 0.35 & 0.13 & 0.02 \\
\hline Career confidence & -.70 & $\mathbf{0 . 3 9}$ & 0.14 & 0.02 \\
\hline \multicolumn{5}{|c|}{ Retention factors canonical variate variables } \\
\hline Compensation & 1.20 & 0.22 & 0.08 & 0.01 \\
\hline Job characteristics & 0.62 & 0.38 & 0.14 & 0.02 \\
\hline Training \& development opportunities & 0.85 & $\mathbf{0 . 5 0}$ & 0.19 & 0.04 \\
\hline Supervisor support & 0.43 & 0.23 & 0.09 & 0.01 \\
\hline Career opportunities & 1.38 & 0.84 & 0.31 & 0.10 \\
\hline Work-life balance & 0.81 & 0.51 & 0.19 & 0.04 \\
\hline Organisational commitment & 0.00 & 0.02 & 0.01 & 0.00 \\
\hline \multicolumn{5}{|l|}{ Overall model fit measures (function 1): } \\
\hline \multicolumn{5}{|l|}{ Overall $R c^{2}=.14$} \\
\hline \multicolumn{5}{|l|}{$\mathrm{F}(p)=2.17(p<.0001) ; \mathrm{df}=35 ; 1302.3$} \\
\hline \multicolumn{5}{|l|}{ Overall proportion: .64} \\
\hline \multicolumn{5}{|l|}{ Wilks' Lambda $(\lambda)=.788 * * *$} \\
\hline \multicolumn{5}{|c|}{$r^{2}$ type effect size: $1-. \lambda=.21$ (moderate practical effect) } \\
\hline Redundancy Index (standardized varian & ntion factor & ained by & cadantah & roportion $=.03$ \\
\hline
\end{tabular}

Notes: $\mathrm{N}=321$. Structure coefficients greater than .30 are in boldface. 


\section{Table 3}

Results of tests for mean differences for race: career adaptability and satisfaction with retention factors

\begin{tabular}{lcccccc}
\hline Variables & $\begin{array}{c}\text { Wilcoxon } \\
\text { statistic }\end{array}$ & $\mathbf{Z}$ & $\boldsymbol{p}$ & $\begin{array}{c}\text { Mean (SD) } \\
\text { Black }\end{array}$ & $\begin{array}{c}\text { Mean (SD) } \\
\text { White }\end{array}$ & Cohen $\boldsymbol{d}$ \\
\hline Career concern & 19477.00 & 6.69 & $<.0001$ & $4.22(.66)$ & $3.63(.63)$ & .91 \\
Career control & 17114.00 & 2.99 & $<.0001$ & $4.18(.61)$ & $3.97(.52)$ & .37 \\
$\begin{array}{l}\text { Career curiosity } \\
\text { Career }\end{array}$ & 17899.00 & 4.21 & $<.0001$ & $4.10(.71)$ & $3.73(.66)$ & .54 \\
$\begin{array}{l}\text { confidence } \\
\text { Compensation }\end{array}$ & 17038.50 & 2.87 & $<.0001$ & $4.25(.66)$ & $4.04(.58)$ & .34 \\
$\begin{array}{l}\text { Job } \\
\text { characteristics }\end{array}$ & 13785.00 & -2.22 & .03 & $3.42(1.30)$ & $3.78(1.08)$ & .30 \\
$\begin{array}{l}\text { Training \& } \\
\text { development }\end{array}$ & 14024.50 & -1.85 & .06 & $4.36(.92)$ & $4.53(.83)$ & \\
$\begin{array}{l}\text { opportunities } \\
\begin{array}{l}\text { Supervisor } \\
\text { support }\end{array}\end{array}$ & 15022.50 & -.29 & .77 & $4.24(1.03)$ & $4.28(1.09)$ & \\
$\begin{array}{l}\text { Career } \\
\text { opportunities }\end{array}$ & 16549.50 & 2.10 & .04 & $3.62(.97)$ & $3.37(.91)$ & .27 \\
$\begin{array}{l}\text { Work-life } \\
\text { balance }\end{array}$ & 17879.00 & 4.18 & $<.0001$ & $4.22(1.11)$ & $3.59(1.23)$ & .54 \\
$\begin{array}{l}\text { Organizational } \\
\text { commitment }\end{array}$ & 13307.50 & -2.99 & .003 & $4.49(1.29)$ & $4.90(1.23)$ & .33 \\
\hline
\end{tabular}

Notes: $\mathrm{n}($ black $)=160 ; \mathrm{n}($ white $)=161$ 
